\title{
Podstawa stosowania warunkowego przedterminowego zwolnienia
}

Postanowienie Sądu Najwyższego z dnia 2 lipca 2019 r., V KK 358/18

Podstawę orzekania o warunkowym przedterminowym zwolnieniu z odbycia reszty kary pozbawienia wolności stanowią kryteria określone w art. 77 \& 1 k.k., nie są natomiast przesłankami rozstrzygania $w$ tym przedmiocie dyrektywy wymiaru kary, określone w art. 53 k.k., art. 54 § 1 k.k. oraz w art. 55 k.k. (art. 56 k.k.).

\section{Maja Sikorska}

Uniwersytet Gdański

majasikorska55@gmail.com

ORCID: 0000-0002-8058-8355

https://doi.org/10.26881/gsp.2020.3.16

\section{Glosa}

Glosowane postanowienie ${ }^{1}$ zostało orzeczone w następującym stanie faktycznym. Sąd Najwyższy (SN) oddalił kasację Prokuratora Generalnego wniesioną na niekorzyść skazanego w przedmiocie warunkowego przedterminowego zwolnienia skazanego, którego prawomocnymi wyrokami uznano za winnego popełnienia następujących przestępstw: zbrodni z art. 148 \& 1 k.k. ${ }^{2}$, przestępstwa z art. $263 \S 2$ k.k., czynu $z$ art. 228 § 3 k.k. i art. 204 § 2 k.k. Skazanemu, łącząc kary jednostkowe za popełnione przestępstwa, wymierzono karę łączną dwudziestu pięciu lat pozbawienia wolności. Skazany rozpoczął odbywanie kary pozbawienia wolności w dniu 19 czerwca 1998 r., a jej koniec - wobec orzeczenia kary łącznej - miał przypaść w dniu 13 czerwca 2023 r. Po piętnastu latach odbywania kary skazany nabył uprawnienie do ubiegania się o warunkowe przedterminowe zwolnienie (2013 r.). Sąd okręgowy (SO) w 2017 r. odmówił udzielenia skazanemu warunkowego przedterminowego zwolnienia. Na skutek wniesionego środka odwoławczego Sąd Apelacyjny (SA) zmienił zaskarżone postanowienie i orzekł m.in. o warunkowym zwolnieniu skazanego z odbycia reszty kary

\footnotetext{
1 Postanowienie SN z dnia 2 lipca 2019 r., V KK 358/18, LEX nr 2690140.

2 Ustawa z dnia 6 czerwca 1997 r. - Kodeks karny (Dz. U. z 2019 r., poz. 1950 ze zm.; dalej: k.k., kodeks karny).
} 
łącznej. Z postanowieniem tym nie zgodził się Prokurator Generalny, który zarzucił we wniesionej kasacji niedokonanie przez sąd odwoławczy wszechstronnej, kompletnej i wnikliwej oceny wszystkich przesłanek wskazanych w art. 77 § 1 k.k., które stanowią podstawę ustalenia prognozy kryminologiczno-społecznej. Skarżący zarzucił pominięcie okoliczności popełnienia przez skazanego przestępstw polegających na tym, że mimo posiadania przez skazanego statusu funkcjonariusza Policji, chronił on przestępczy proceder i czerpał z tego korzyści. Skarżący podniósł również fakt orzeczenia kary łącznej dwudziestu pięciu lat pozbawienia wolności i skazania za zbrodnię zabójstwa. W ocenie skarżącego te okoliczności miały znaczyć o skłonności skazanego do instrumentalnego traktowania innych osób, podejmowania bezwzględnych decyzji. Zdaniem skarżącego, nie powinna zostać przyjęta - jako prawidłowa - ocena, że krytyczny stosunek skazanego do popełnionych przestępstw był ugruntowany. Ponadto, nie świadczy o tym również zachowanie skazanego w zakładzie karnym w trakcie odbywania kary, polegające na przestrzeganiu regulaminu i otrzymywaniu nagród, ponieważ nie jest to samodzielna podstawa do warunkowego przedterminowego zwolnienia.

Sąd Najwyższy, oddalając kasację, wskazał w uzasadnieniu, że „podstawę orzekania o warunkowym przedterminowym zwolnieniu z odbycia reszty kary pozbawienia wolności stanowią kryteria określone w 77 § 1 k.k., nie są natomiast przesłankami rozstrzygania w tym przedmiocie dyrektywy wymiaru kary określone w art. 53 k.k., art. 54 $\S 1$ k.k. oraz w art. 55 k.k. (art. 56 k.k.)". Sąd podniósł, że charakter popełnionych przestępstw nie może wpływać na decyzję dotyczącą warunkowego przedterminowego zwolnienia, ponieważ przesłanka ta nie jest zawarta w katalogu określonym w art. 77 § 1 k.k. Ponadto, SN stwierdził, że sąd odwoławczy dokonał pozytywnej oceny prognozy kryminologicznej, biorąc pod uwagę aktualne właściwości i warunki osobiste skazanego, oraz w przekonaniu, że skazany po zwolnieniu będzie przestrzegał porządku prawnego i nie popełni ponownie przestępstwa. W ocenie sądu odwoławczego, cele kary zostały osiągnięte i resocjalizacja może być kontynuowana poza zakładem karnym. Ponadto, zdaniem SN, okoliczności popełnienia czynu nie mogą mieć większego znaczenia niż pozostałe przesłanki wskazane w katalogu podstaw stosowania warunkowego przedterminowego zwolnienia, ponieważ instytucja ta stałaby się całkowicie zależna od okoliczności popełnienia przestępstwa i niezależna od postępów resocjalizacji sprawcy.

Finalne stanowisko SN wyrażone w glosowanym postanowieniu zasługuje na aprobatę, jednak - zdaniem autorki glosy - mogłoby zostać uzupełnione o dodatkowe argumenty. Na szczególną uwagę zasługują ukazane różnice pomiędzy przesłanką "charakteru przestępstwa" a "okolicznościami popełnienia przestępstwa" w relacji do badania prognozy kryminologicznej skazanego, stanowiącej podstawę do warunkowego przedterminowego zwolnienia. Mimo podkreślenia różnicy pomiędzy tymi przesłankami oraz trafnego ostatecznego stanowiska SN, zdaniem autorki glosy, w uzasadnieniu prawnym w sposób szablonowy odwołano się do orzeczeń innych sądów, nie przedstawiając w sposób wyczerpujący zagadnień związanych z przedmiotową sprawą, do czego odnieść należy się krytycznie. 
W pierwszej kolejności, w zakresie uwag generalnych, zaznaczyć należy, że zasadą jest odbywanie przez skazanego kary w całości, a jedynie w uzasadnionych wypadkach możliwość warunkowego przedterminowego zwolnienia z jej wykonania ${ }^{3}$. Istotą tej instytucji jest zrezygnowanie po określonym czasie od skazania z wykonywania orzeczonej przez sąd kary pozbawienia wolności przed upływem okresu jej wykonywania. Umożliwia to nieponoszenie kosztów związanych z izolacją sprawcy, gdy nie zachodzi już taka potrzeba ${ }^{4}$, a instytucja pozwalać ma na realizację racjonalnej polityki karnej. Zauważyć trzeba, że udzielenie przez sąd warunkowego przedterminowego zwolnienia ma charakter fakultatywny ${ }^{5}$ i może nastąpić po spełnieniu określonych przesłanek. Instytucja ta nie jest prawem podmiotowym skazanego ${ }^{6}$. Oznacza to, że sąd ma możliwość, a nie obowiązek zastosowania takiego warunkowego przedterminowego zwolnienia wobec skazanego wyłącznie w określonych przypadkach.

Pozytywna prognoza kryminologiczna stanowi materialną przesłankę możliwości zastosowania przez sąd penitencjarny warunkowego przedterminowego zwolnienia. Przesłankami do dokonania pozytywnej prognozy kryminologicznej, zgodnie z art. 77 $\S 1$ k.k., są: (i) postawa sprawcy; (ii) jego właściwości i warunki osobiste; (iii) okoliczności popełnienia przestępstwa; (iv) zachowanie po popełnieniu przestępstwa; (v) zachowanie w czasie odbywania kary. Przesłanki te muszą wywołać przekonanie sądu co do stosowania się przez skazanego w warunkach wolnościowych do orzeczonego środka karnego lub zabezpieczającego, przestrzegania porządku prawnego, w tym niepopełnienia ponownie przestępstwa. Do wejścia w życie nowelizacji k.k. z 2011 r. konieczne było także branie pod uwagę przesłanki polegającej na ocenie sposobu życia przed popełnieniem przestępstwa, jednak - jak wskazują komentatorzy doktryny - została ona zasadnie wyeliminowana z treści przepisu, gdyż aspekt życia sprzed popełnienia przestępstwa analizowany jest przez sąd zgodnie z art. 53 k.k. na etapie wymiaru kary ${ }^{8}$.

W świetle ww. art. 77 § 1 k.k. wątpliwości mogą budzić zarzuty Prokuratora Generalnego podniesione w skardze kasacyjnej co do konieczności brania przez sąd pod uwagę charakteru popełnionego przestępstwa jako jednej z przesłanek zastosowania warunkowego przedterminowego zwolnienia. Jak podnosi się w doktrynie, przesłanki z art. $77 \S 1$ k.k. zostały wskazane w sposób zupełny, co oznacza, że sąd - wydając orzeczenie o udzieleniu lub odmowie udzielania warunkowego przedterminowego zwolnienia - nie może brać pod uwagę takich czynników, jak m.in. stopień społecznej

3 Tak w postanowieniu SA w Krakowie z dnia 27 czerwca 2000 r., II AKz 214/00, KZS 2000, nr 7-8, poz. 54 [cyt. za:] M. Kulik, Art. 77. Podstawy stosowania warunkowego przedterminowego zwolnienia [w:] Kodeks karny. Komentarz, red. M. Mozgawa, LEX/el.

${ }^{4}$ V. Konarska-Wrzosek, Art. 77. Warunkowe przedterminowe zwolnienie - przesłanki materialne. Wyznaczenie surowszych ograniczeń warunkowego zwolnienia [w:] Kodeks karny. Komentarz, red. eadem, LEX/el.

5 Ibidem; M. Kulik, Art. 77. Podstawy stosowania...

6 A. Zoll, Komentarz do art. 53-116 [w:] Kodeks karny. Część ogólna, red. idem, W. Wróbel, t. 1, LEX/el.

7 Ustawa z dnia 16 września 2011 r. o zmianie ustawy - Kodeks karny wykonawczy oraz niektórych innych ustaw (Dz. U. Nr 240, poz. 1431 ze zm.).

8 P. Hofmański, L.K. Paprzycki, A. Sakowicz, Art. 77. Podstawy stosowania warunkowego przedterminowego zwolnienia [w:] Kodeks karny. Komentarz, red. M. Filar, LEX/el. 
szkodliwości przestępstwa, kwestii sprawiedliwościowych czy konieczności kształtowania prawnej świadomości społeczeństwa oraz rodzaju lub charakteru9 popełnionego przestępstwa. Analiza innych przesłanek niż wskazane w art. 77 § 1 k.k. - zdaniem niektórych komentatorów doktryny - stanowi „obrazę tego materialnego przepisu”10. Wobec tego część doktryny wyraża pogląd, że przy podejmowaniu decyzji o warunkowym przedterminowym zwolnieniu nie uwzględnia się przesłanek określonych w art. 53 k.k., który dotyczy sądowych dyrektyw wymiaru kary. Zaznaczyć jednak trzeba, że doktryna nie była w tym zakresie jednolita - podnoszono, że przesłanek z art. 77 $\S 1$ k.k. nie można badać $w$ całkowitym oderwaniu od innych przepisów, w tym właśnie dyrektyw wymiaru kary z art. 53 k.k. Aktualnie w doktrynie wskazuje się, że stanowisko co do konieczności stosowania dyrektyw z art. 53 k.k. do instytucji z art. $77 \S 1$ k.k. może być trudne do obrony w świetle obowiązującego kodeksu karnego ${ }^{11}$. Obecnie zaznacza się $w$ linii orzeczniczej dominację pierwszego ze wskazanych poglądów, na co miała wpływ uchwała SN z dnia 26 kwietnia 2017 r. składu siedmiu sędziów w sprawie I KZP 2/17'2.

Jednym ze źródeł wątpliwości mógł być art. 56 k.k. stanowiący o odpowiednim stosowaniu przepisów o dyrektywach wymiaru kary do orzekania innych środków przewidzianych w kodeksie karnym. Stwierdzić jednak należy, że ich zastosowanie będzie miało miejsce jedynie w przypadku, gdy będzie to w zgodzie $z$ istotą oraz charakterem prawnym danej instytucji. Dyrektywy sądowego wymiaru kary - oprócz dyrektywy prewencji indywidualnej zbiegającej się z przesłanką materialną art. 77 k.k. - nie uwzględniają istoty i specyfiki instytucji przedterminowego warunkowego zwolnienia, ponieważ wykonywanie kary pozbawienia wolności jest ukierunkowane na indywidualne oddziaływanie na konkretną osobę - skazanego ${ }^{13}$. Oznacza to, że racjonalizacja indywidualnoprewencyjna stanowi podstawę warunkowego przedterminowego zwolnienia, a cele wykonania kary pozbawienia wolności muszą zostać osiągnięcie co najmniej w części. Racjonalizacja indywidualnoprewencyjna przejawia się właśnie w celu wychowawczym (art. 67 k.k.w.) polegającym m.in. na wywołaniu u skazanego poczucia co do konieczności przestrzegania porządku prawnego ${ }^{14}$.

W powyższym kontekście zwraca się w doktrynie i judykaturze znaczną uwagę na proces resocjalizacji i konieczność badania przez sąd, czy ewolucja w zachowaniu sprawcy jest widoczna, trwała oraz czy pozwoli osiągnąć cele kary. Elementy negatywne zaobserwowane na początku okresu odbywania kary nie mogą stanowić trwałej

9 Zob. postanowienia: SA w Krakowie z dnia 25 lutego 1999 r., II AKz 53/99, KZS 1999, nr 3, poz. 27; z dnia 13 października 1999, II AKz 467/99, KZS 1999, nr 10, poz. 42; ponadto zob.: uchwała SN z dnia 26 kwietnia 2017 r., I KZP 2/17, OSNKW 2017, nr 6, poz. 32; postanowienie SN z dnia 24 maja 2017 r., V KK 82/17, LEX nr 2319706 [cyt. za:] M. Kulik, Kodeks karny...

10 J. Lachowski [w:] Kodeks karny. Część ogólna, red. M. Królikowski, R. Zawłocki, 2017, s. 1045 [cyt. za:] V. Konarska-Wrzosek, Art. 77. Warunkowe przedterminowe zwolnienie...

11 A. Zoll, Komentarz do...; zob. też postanowienie SA w Gdańsku z dnia 18 października 2000 r., II AKz 943/00, Prok. i Pr.-wkł. 2001, nr 4, poz. 21.

12 K. Janczukowicz, Stosowanie ogólnych dyrektyw wymiaru kary przy warunkowym zwolnieniu, LEX/el.

13 J. Lachowski, Instytucja warunkowego przedterminowego zwolnienia, PiP 2008, nr 2, s. 110-121.

14 Ibidem. 
przeszkody do udzielenia skazanemu warunkowego przedterminowego zwolnienia. Resocjalizacja ma charakter rozwojowy i ewolucyjnie może doprowadzić do zmiany zachowania skazanego, kształtując w skazanym pozytywne i pożądane postawy ${ }^{15}$. Kwestia resocjalizacji i osiągnięcia celów indywidualnoprewencyjnych jest o tyle istotna, że zarzut podniesiony przez Prokuratora Generalnego, dotyczący niewzięcia pod uwagę przez sąd odwoławczy charakteru popełnionego przestępstwa, ma znaczenie w kolizji przesłanek indywidualnoprewencyjnych z ogólnymi dyrektywami wymiaru kary. Skoro warunkowe przedterminowe zwolnienie jest instytucją szczególnoprewencyjną, to należy uznać, że słusznie orzekł SN w glosowanym postanowieniu, że charakter popełnionych przestępstw jest poza katalogiem ustawowych przesłanek wpływających na decyzję w przedmiocie udzielenia warunkowego przedterminowego zwolnienia. Dodać należy, że charakter popełnionego przestępstwa nie może wpływać na decyzję sądu o warunkowym przedterminowym zwolnieniu - w przeciwnym wypadku mogłoby to powodować orzeczenie decyzji o warunkowym przedterminowym zwolnieniu ponownie opartej na tych przesłankach, które decydowały o wymiarze kary. Gdyby w badaniu prognozy kryminologicznej decydujący wpływ miał charakter popełnionego przestępstwa, to - zdaniem autorki glosy - każde zachowanie sprawcy w trakcie odbywania kary pozbawienia wolności oceniane byłoby w świetle czynu, na który skazani nie mają już wpływu w trakcie odbywania kary, i za którego popełnienie odbywają karę pozbawienia wolności. Przyjęcie takiej przesłanki jako podstawy skorzystania z dobrodziejstwa warunkowego przedterminowego zwolnienia mogłoby powodować zmniejszoną chęć skazanych do resocjalizacji, ponieważ ich zachowanie zawsze byłoby oceniane i tak przez pryzmat czynu już popełnionego.

Jak wskazano powyżej, charakter popełnionego przestępstwa jest poza katalogiem ustawowych przesłanek pozwalających na dokonanie prognozy oceny kryminologicznej. Nie dotyczy to jednak okoliczności popełnienia przestępstwa, które stanowią jedną z enumeratywnych przesłanek będących podstawą do zastosowania warunkowego przedterminowego zwolnienia. Jako okoliczności takie wskazuje się wszelkie fakty oraz sytuacje, które towarzyszą popełnianemu przestępstwu i które pozostają z czynem sprawcy w związku czasowo-sytuacyjnym ${ }^{16}$. Za okoliczności popełnienia przestępstwa nie mogą być uznane znamiona popełnionego czynu, ponieważ determinują one rodzaj popełnionego czynu, a byłoby to wprowadzenie nowej przesłanki do katalogu z art. 77 § 1 k.k. ${ }^{17}$

Niewątpliwie analiza przesłanek materialnych oraz ocena ich wartości może być zadaniem trudnym. Wobec wymienienia okoliczności popełnienia czynu w treści ww. przepisu powinny one być przedmiotem oceny przez sąd penitencjarny, jednak jak się przyjmuje - i co słusznie zaznaczył SN w glosowanym postanowieniu - istnieje

\footnotetext{
15 Zob. postanowienie SA w Lublinie z dnia 12 października 2005 r., II AKzw 594/05, LEX nr 166014 [cyt. za:] A. Zoll, Komentarz do...

16 J. Skupiński, J. Mierzwińska-Lorencka, Art. 77 KK [w:] Kodeks karny. Komentarz, red. R. Stefański, Legalis.

17 Zob. S. Lelental, Warunkowe przedterminowe zwolnienie [w:] System Prawa Karnego, red. M. Melezini, t. 6, 2016, s. 1173 i n. [cyt. za:] J. Skupiński, J. Mierzwińska-Lorencka, Art. 77 KK...
} 
potrzeba kumulatywnej oceny przesłanek, a nie konieczność kumulatywnego zaistnienia wszystkich przesłanek ${ }^{18}$. Po kumulatywnej analizie przesłanek z art. 77 § 1 k.k sąd dokonuje oceny, czy wobec skazanego zachodzi pozytywna prognoza kryminologiczna. W doktrynie wyraża się stanowisko, że należy uwzględnić wszystkie przesłanki, zarówno pozytywne, jak i negatywne, a ocena ma mieć charakter kompleksowy. Przesłanki te nie są jednak równorzędne, a największe znaczenie powinna mieć przesłanka dotycząca zachowania sprawcy w trakcie odbywania kary ${ }^{19}$. Zauważa się także, że okoliczności popełnienia czynu powinny mieć - w ocenie prognozy kryminologicznej - znaczenie jedynie pomocnicze i nie mają zasadniczego znaczenia dla prognozy negatywnej. ${ }^{20}$

Trafnie zatem należy ocenić argumentację SN co do prawidłowości dokonania przez sąd odwoławczy prognozy kryminologicznej na podstawie oceny wszystkich przesłanek z art. 77 § 1 k.k., ze szczególnym uwzględnieniem oceny aktualnych warunków i właściwości sprawcy, jego zachowania w trakcie odbywania kary pozbawienia wolności, w tym - otrzymywania licznych nagród za dobre sprawowanie w warunkach izolacji, analizę najbardziej aktualnej opinii psychologicznej i nadanie drugorzędnego znaczenia opinii psychologicznej z początkowego okresu odbywania kary.

Zdaniem autorki glosy, w odniesieniu do powyższego, SN mógłby jednak w przedmiotowej sprawie bardziej szczegółowo przedstawić argumentację w odniesieniu do zarzutów skarżącego oraz uwypuklić kwestię problemu ustalenia pozytywnej prognozy kryminologicznej.

W jednym z zarzutów wnoszący kasację podniósł, że sąd nie dokonał "wszechstronnej, kompletnej i wnikliwej oceny, zgodnie z zasadą swobodnej oceny dowodów", podkreślając przy tym negatywne aspekty zachowania sprawcy, które miały w rezultacie spowodować negatywną ocenę prognozy kryminologicznej. Niestety zauważyć należy, że SN w niektórych miejscach odniósł się lakonicznie do przesłanek ustawowych, powielając przy tym stanowiska innych sądów, oraz nie podniósł, że niektóre z zarzutów skarżącego - np. brak długotrwałego krytycyzmu przez skazanego wobec przestępstwa ${ }^{21}$ - znajdują się poza katalogiem ustawowych przesłanek do zastosowania warunkowego zwolnienia. Sąd, odnosząc się do powyższego zarzutu skarżącego, stwierdza jedynie, że „nie wiadomo też, na jakiej podstawie skarżący wywodzi przekonanie, że »aktualna postawa skazanego w przedmiocie krytycznego stosunku do popełnionych przestępstw« nie jest w pełni zinternalizowana". Takie odniesienie się do zarzutu skarżącego - w ocenie autorki glosy - nie wnosi wartości do uzasadnienia prawnego.

\footnotetext{
18 A. Zoll, Komentarz do...

19 J. Skupiński, J. Mierzwińska-Lorencka, Art. 77 KK...

20 S. Lelental, Warunkowe przedterminowe zwolnienie [w:] System... [cyt. za:] J. Skupiński, J. Mierzwińska-Lorencka, Art. 77 KK...; ponadto zob. postanowienie SA w Lublinie z dnia 27 grudnia 2007 r., II AKzw 1075/07, OSA 2008, z. 11, poz. 55.

21 T. Kalisz, Warunkowe zwolnienie z reszty odbywania kary pozbawienia wolności z perspektywy problemów z ustalaniem treści i kierunków prognozy kryminologicznej, NKPK 2013, t. 30, s. 184, https://wuwr. pl/nkp/article/view/7994/7627 [dostęp: 16.07.2020].
} 
Ponadto, dużym walorem orzeczenia byłoby rozszerzenie wątku istoty prognozy kryminologicznej. Mimo że w treści art. 77 § 1 k.k. nie wskazano expressis verbis definicji prognozy kryminologicznej, to jej opis można wywnioskować z przesłanek zawartych w tym przepisie. Niewątpliwie w literaturze zwraca się uwagę na wagę zagadnienia prognozy kryminologicznej w prawie karnym wykonawczym. Określa się ją również jako przewidywanie przyszłych zdarzeń, uzasadnionych na podstawie określonych przesłanek dotyczących skazanego ${ }^{22}$. Autorka glosy podnosi, że pomimo tego, że SN odniósł się do konieczności kumulatywnej oceny wszystkich przesłanek decydujących o wyniku prognozy kryminologicznej, to pominął kwestię, która mogłaby stanowić argument przeciwko zarzutom skarżącego. Warte dodania byłoby, że pozytywna prognoza kryminologiczna, będąca podstawą zastosowania warunkowego przedterminowego zwolnienia, jest przekonaniem sądu, a nie gwarancją co do określonego zachowania sprawcy w przyszłości. Wskazane w art. 77 § 1 k.k. przesłanki prognozowania mogą sprawiać wiele trudności w ich ustaleniu, o czym świadczą rozbieżne orzeczenia sądów penitencjarnych, jednak w doktrynie krytykuje się stanowiska sądów uznające, że pozytywna prognoza kryminologiczna powoduje „przekonanie, iż w trakcie odbywania kary nastąpiła trwała i pozytywna zmiana zachowania skazanego, co gwarantuje [podkr. M.S.], iż po zwolnieniu będzie przestrzegał porządku prawnego i nie popełni przestępstwa"23. Przekonanie, zdaniem komentatorów doktryny, jest odczuciem silniejszym niż przypuszczenie, ale jednak nie może być zrównanie z pewnością. Przekonanie sądu jest prawdopodobieństwem, które może być mierzone w stopniu większym lub mniejszym, a „obszar pomiędzy prawdopodobieństwem a pewnością należy wypełnić ryzykiem tego, że prognoza może się nie sprawdzić"24. Oznacza to, że sąd nie musi mieć gwarancji co do przestrzegania porządku prawnego w przyszłości przez skazanego, a jedynie (i aż) przekonanie w tym zakresie, które może być ujęte w różnym stopniu. Stwierdzić zatem należy, że wystąpienie jednej przesłanki negatywnej nie może determinować całościowej negatywnej oceny prognozy kryminologicznej; przekonanie budowane jest na podstawie wszystkich przesłanek dotyczących warunkowego przedterminowego zwolnienia. Co więcej, gdyby przyjąć, że intencją ustawodawcy było wprowadzenie gwarancji sądu m.in. w zakresie przestrzegania porządku prawnego w przyszłości przez skazanego, to wówczas nieracjonalne byłoby wprowadzenie obowiązkowego okresu próby w przypadku skorzystania przez skazanego z dobrodziejstwa warunkowego przedterminowego zwolnienia, możliwości jego odwołania (okres spędzony na wolności nie jest zaliczany na poczet kary pozbawienia wolności) oraz oddania skazanego pod dozór kuratora czy nałożenia

\footnotetext{
22 P. Stępniak, Udział skazanego w kształtowaniu prognozy kryminologicznej, „Przegląd Więziennictwa Polskiego" 2008, nr 61, s. 49 i n., https://www.sw.gov.pl/assets/33/86/35/9710833675c6cee5151d0f0afeddfb4e8d540243.pdf\#page=49) [dostęp: 16.07.2020].

23 Zob. postanowienie SA w Katowicach z dnia 11 grudnia 2008 r., II AKZW 1459/08, Prok. i Pr. 2009, nr 10, poz. 23 [cyt. za:] S. Lelental, Kary i środki karne. Poddanie sprawcy próbie [w:] System Prawa Karnego, red. M. Melezini, t. 6, Legalis [dostęp: 15.07.2020].

24 Zob. J. Lachowski [w:] Kodeks karny, red. M. Królikowski, R. Zawłocki, t. 1, 2015, s. 426 [cyt. za:] J. Skupiński, J. Mierzwińska-Lorencka, Art. 77 KK...
} 
innych obowiązków, co sąd penitencjarny uczynił w niniejszym przypadku. Wskazać przy tym należy, że nawet w przypadku skazania sprawcy za dokonaną zbrodnię na karę dwudziestu pięciu lat pozbawienia wolności (tak jak w przedmiotowej sprawie), art. 80 § 3 k.k. przewiduje dłuższy okres próby, który wynosi dziesięć lat. Gdyby intencją ustawodawcy było wykluczenie podmiotowe sprawców, którym wymierzono karę pozbawienia wolności wynoszącą dwadzieścia pięć lat, z podmiotów uprawnionych do skorzystania z warunkowego przedterminowego zwolnienia, to ustawodawca nie wprowadzałby szczegółowych postanowień w ww. art. 80 § 3 k.k.

Jak wyżej wspomniano, z pewnością sądu co do przyszłych zdarzeń - przestrzegania przez skazanego porządku oraz niepopełnienia przestępstwa - związane jest również ryzyko, że prognoza może się nie sprawdzić. Jak ciekawie podnosi Barbara Stańdo-Kawecka, zachodzące zmiany we współczesnej kryminologii i prawie karnym prowadzą do wykształcenia się nowego paradygmatu - paradygmatu ryzyka. Zarządzanie ryzykiem, zwane też risk management, stanowi trend w podejściu do przestępczości, w tym szacowania ryzyka w okresie wykonywania sankcji karnych ${ }^{25}$. Podkreśla się przy tym, że w zakresie oceny ryzyka istotne znaczenie mają badania osobopoznawcze (np. badanie przez biegłego psychologa) ${ }^{26}$. Zauważa się również, że dokonanie oceny prognozy kryminologicznej nie jest oparte w praktyce z reguły na takich badaniach, a zastąpione suchą oceną przesłanek materialnoprawnych ${ }^{27}$. Zgodnie z tym, zasadne wydaje się przywiązywanie wagi do badań psychologicznych sprawcy przestępstwa przy dokonywaniu oceny prognozy kryminologicznej, co też słusznie wziął pod uwagę SN w niniejszej sprawie.

Podsumowując powyższe, stwierdzić należy, że niewątpliwie w badaniu prognozy pominięte powinny być znamiona popełnionego przez sprawcę czynu - jako świadczące o charakterze przestępstwa, ponieważ znajdują się poza katalogiem ustawowych przesłanek. Zdaniem autorki glosy, w ocenie prognozy kryminologicznej nie można ignorować całkowicie przesłanek dotyczących okresu wcześniejszego, w tym okoliczności popełnienia przestępstwa, ale nie powinny one mieć charakteru przeważającego nad innymi przesłankami. Kumulatywna ocena przesłanek dotyczących prognozy powinna większą wagę przywiązywać do okresu możliwie najnowszego. To właśnie ocena najbardziej aktualnego zachowania sprawcy, jego aktywność w gotowości przestrzegania porządku prawnego pozwala stwierdzić, czy cele kary zostały spełnione i dalsza resocjalizacja sprawcy może odbywać się w warunkach wolnościowych. Istotne jednak jest, że ocena sądu dokonującego analizy przesłanek do warunkowego przedterminowego zwolnienia ma stanowić przekonanie sądu, a nie gwarancję, że skazany będzie w przyszłości przestrzegał porządku prawnego i nie popełni przestępstwa. Istnieje jednak ryzyko, że przekonanie to może być błędne, dlatego niezwykle ważne jest zarządzenie tym ryzykiem m.in. poprzez szczegółowe odniesienie

\footnotetext{
25 B. Stańdo-Kawecka, Paradygmaty karania a badania osobopoznawcze sprawców przestępstw, NKPK 2019, tom 51, s. 27 i n., https://wuwr.pl/nkp/article/view/8246/7879 [dostęp: 16.07.2020].

26 Ibidem.

27 P. Stępniak, Udział skazanego w kształtowaniu...
} 
się przez sądy do wszystkich przesłanek ustawowych, z uwzględnieniem realiów konkretnej sprawy, bez szablonowego powielania orzeczeń innych sądów - oraz w miarę możliwości - z uwzględnieniem badań osobopoznawczych. Należy pamiętać jednak, że wystąpienie negatywnych przesłanek, przy założeniu przewagi pozytywnych, nie może skutkować negatywną prognozą kryminologiczną, ponieważ oprócz tego, że prognoza kryminologiczna powinna być dokonywana poprzez kumulatywną ocenę przesłanek z art. 77 § 1 k.k., to w zakres zarządzania ryzykiem wchodzą też różne okresy próby wskazane w art. 80 k.k. oraz możliwość nałożenia przez sąd na skazanego dodatkowych obowiązków, takich jak np. zakaz opuszczania stałego miejsca pobytu.

\section{Literatura}

Hofmański P., Paprzycki L. K., Sakowicz A., Art. 77. Podstawy stosowania warunkowego przedterminowego zwolnienia [w:] Kodeks karny. Komentarz, red. M. Filar, LEX/el. [dostęp: 7.06.2020].

Janczukowicz K., Stosowanie ogólnych dyrektyw wymiaru kary przy warunkowym zwolnieniu, LEX/el. [dostęp: 7.06.2020].

Kalisz T., Warunkowe zwolnienie z reszty odbywania kary pozbawienia wolności z perspektywy problemów z ustalaniem treści i kierunków prognozy kryminologicznej, NKPK 2013, t. 30.

Konarska-Wrzosek V., Art. 77. Warunkowe przedterminowe zwolnienie - przesłanki materialne. Wyznaczenie surowszych ograniczeń warunkowego zwolnienia [w:] Kodeks karny. Komentarz, red. eadem, LEX/el.

Kulik M., Art. 77. Podstawy stosowania warunkowego przedterminowego zwolnienia [w:] Kodeks karny. Komentarz, red. M. Mozgawa, LEX/el.

Lachowski J., Instytucja warunkowego przedterminowego zwolnienia, PiP 2008, nr 2, LEX/el.

Lachowski J. [w:] Kodeks karny. Część ogólna, red. M. Królikowski, R. Zawłocki, Warszawa 2017.

Lelental S., Kary i środki karne. Poddanie sprawcy próbie [w:] System Prawa Karnego, red. M. Melezini, t. 6, Warszawa 2010.

Lelental S., Warunkowe przedterminowe zwolnienie [w:] System Prawa Karnego, red. M. Melezini, t. 6, Warszawa 2016.

Skupiński J., Mierzwińska-Lorencka J., Art. 77 KK [w:] Kodeks karny. Komentarz, red. R. Stefański, Legalis.

Stańdo-Kawecka B., Paradygmaty karania a badania osobopoznawcze sprawców przestępstw, NKPK 2019, t. 51.

Stępniak P., Udział skazanego w kształtowaniu prognozy kryminologicznej, „Przegląd Więziennictwa Polskiego" 2008, nr 61.

Zoll A., Komentarz do art. 53-116 [w:] Kodeks karny. Część ogólna, red. idem, W. Wróbel, t. 1, LEX/el. 


\section{Streszczenie}

\section{Maja Sikorska}

\section{Podstawa stosowania warunkowego przedterminowego zwolnienia}

W glosowanym postanowieniu SN odniósł się do kwestii podstawy stosowania warunkowego przedterminowego zwolnienia, w tym analizy zagadnienia pozytywnej prognozy kryminologicznej. Autorka glosy aprobująco odnosi się do stanowiska SN, że charakter popełnionych przestępstw nie może wpływać na decyzję o warunkowym przedterminowym zwolnieniu. Ponadto, niezasadne jest nadawanie większego znaczenia okolicznościom popełnienia czynu, niż wszystkim pozostałym przesłankom wskazanym w art. 77 § 1 k.k., stanowiącym podstawę do zastosowania warunkowego przedterminowego zwolnienia. W przeciwnym wypadku instytucja ta stałaby się całkowicie zależna od okoliczności popełnienia przestępstwa i niezależna od postępów resocjalizacji sprawcy. Jednakże - w opinii autorki glosy - argumentacja sądu mogłaby być uzupełniona o dodatkowe argumenty, w tym sąd mógłby zwrócić uwagę na istotę prognozy kryminologicznej, która stanowi przekonanie, a nie gwarancję, że skazany będzie przestrzegał porządku prawnego i nie popełni ponownie przestępstwa.

\section{Summary}

\section{Maja Sikorska}

\section{Basis for applying a conditional early release}

In the analyzed decision, the Supreme Court referred to the issue of the basis for the application of a conditional early release, including the analysis of the issue of positive criminological prognosis. The author expresses her approval for the Supreme Court's position that the nature of committed crimes cannot influence the decision on the conditional early release. Moreover, it is not justified to give greater significance to the circumstances of committing a crime than to all other conditions specified in art. $77 \S 1$ of the Penal Code, which constitutes the basis for the application of the conditional early release. Otherwise, the institution would become fully dependent on the circumstances of the commission of the crime and independent of the progress of social rehabilitation of the perpetrator. However, in the opinion of the author, the court's argumentation could be supplemented by additional arguments, including that the court could draw attention to the essence of the criminological prognosis, which is a conviction rather than a guarantee that the sentenced person will obey the legal order and not commit the crime again.

Słowa kluczowe: warunkowe przedterminowe zwolnienie, okoliczności popełnienia przestępstwa, pozytywna prognoza kryminologiczna

Keywords: conditional early release, circumstances of the commission of a crime, positive criminological prognosis 